MAKSIMUM: Media Akuntansi Universitas Muhammadiyah Semarang, Vol.10 (1) 2020, 23-30

https://jurnal.unimus.ac.id/index.php/MAX

Registered with the Indonesian Institute of Sciences with p-ISSN: $2087-$ 2836 and e-ISSN: 2580-9482

\title{
Analisis Pengaruh Profitabilitas, Financial Leverage dan Dividen Payout Ratio Terhadap Income Smoothing Pada Perusahaan Manufaktur Yang Terdaftar Di Bursa Efek Indonesia Periode 2014 - 2018
}

\author{
Muhamad Khoirul Kabib ${ }^{1}$, Hardiwonoto², Ida Kristiana ${ }^{3}$ \\ ${ }^{123}$ Fakultas Ekonomi, Universitas Muhammadiyah Semarang, Indonesia
}

\section{Info Article}

History Article:

Submitted: 20 Januari

2020

Revised: 30 Januari

2020

Accepted: 20 Februari

2020

Keywords:

profitabilitas, financial leverage, dividen payout ratio, income smoothing

JEL classifications: G22, G13

\begin{abstract}
This study was structured to determine the significance level of the Profitability, Financial Leverage and Dividend Payout Ratio variables against Income Smoothing in Manufacturing Companies listed on the IDX for the 2014-2018 period. This study used a purposive sampling technique. The sample used in this study were 49 companies listed on the Indonesia Stock Exchange (BEI). Data obtained from the company's financial statements for 2014-2018. The analysis used in this study is multiple regression analysis to determine the effect of Profitability, Financial Leverage and Dividend Payout Ratio on Income Smoothing at Manufacturing Companies listed on the IDX for the 2014-2018 period. Based on the classic assumption test, namely normality test, heteroscedasticity test, multicollinearity test, and the autocorrelation test found no deviation. This shows that the available data has met the requirements for use in multiple linear regression equation models. The results of the partial analysis show that the Profitability and Financial Leverage variables have a significant positive effect on Income Smoothing. Meanwhile, the Dividend Payout Ratio variable has a negative and insignificant effect on income smoothing. Meanwhile, the simultaneous test results show that the three variables have a significant positive effect on income smoothing. The predictive ability of the three variables on Income Smoothing was $32.8 \%$, while the other $67.2 \%$ were explained by other variables outside the independent variables in the study.
\end{abstract}

How to Cite: Kabib,M.,K., Hardiwinoto., Kristiana, I. (2020). Analisis Pengaruh Profitabilitas, Financial Leverage Dan Dividen Payout Ratio Terhadap Income Smoothing Pada Perusahaan Manufaktur Yang Terdaftar Di Bursa Efek Indonesia Periode 2014 - 2018. MAKSIMUM, Vol..10(1), 23-30

${ }^{\square}$ correspondence Address: Jl. Kedungmundu No.18, Kedungmundu, Kec. Tembalang, Kota 2086-0668 (P-ISSN)

Semarang, Jawa Tengah 50273 2337-5434 (e-ISSN)

Institutional address: Universitas Muhammadiyah Semarang

E-mail: 


\section{PENDAHULUAN}

Laporan keuangan adalah dokumen perusahaan yang melaporkan sebuah perusahaan dalam istilah moneter. Laporan keuangan terdiri dari laporan ekuitas pemilik modal, neraca, laporan arus kas dan laporan laba rugi (Harrison, 2007). Laporan keuangan merupakan bentuk cerminan dari kondisi perusahaan karena didalamnya terdapat informasi yang dibutuhkan oleh pihak - pihak yang berkepentingan dengan perusahaan. Sebuah laporan keuangan disusun oleh manajemen perusahaan untuk mengambil keputusan ekonomi, keputusan bisnis dan berbagai keputusan perusahaan lainnya. Maka dari itu, informasi yang terdapat pada laporan keuangan harus relevan, dapat di pahami dan andal.

Informasi yang terdapat pada laporan keuangan sangat dibutuhkan bagi pihak pihak yang berkepen-tingan dengan perusahaan. Biasanya para kreditor dan investor menitik beratkan informasi yang ingin mereka peroleh pada laporan laba - rugi suatu perusahaan. Laporan laba - rugi merupakan selisih antara total pendapatan dan total biaya perusahaan digunakan untuk menilai kinerja manajemen tanpa mem-perhatikan prosedur yang digunakan untuk memperoleh laba perusahaan. Laporan laba - rugi yang digunakan untuk menilai kinerja manajemen perusahaan dapat mendorong terjadinya perilaku tidak semestinya (disfungsional behavior) karena manajemen cenderung akan melakukan tindakan yang membuat laporan keuangan menjadi lebih baik.

Income smoothing adalah proses manipulasi waktu terjadinya laba atau laporan laba agar laba yang dilaporkan terlihat stabil (Syahriana, 2007). Laba yang memiliki citra baik lebih disukai dimata pihak eksternal karena dapat menggambarkan tingkat resiko yang rendah jika dibandingkan dengan yang berfluktuatif. Income smoothing lebih disebabkan karena manajemen lebih memilih untuk menjaga nilai laba yang stabil di bandingkan dengan yang berf-luktuatif.

Sehingga manajemen menaikkan laba yang di laporkan jika laba yang mereka peroleh sebenarnya menurun dibandingkan tahun sebelumnya, ataupun sebaliknya. Manajemen akan memilih untuk menurunkan laba yang dilaporkan jika laba yang sebenarnya meningkat di bandingkan laba tahun sebelumnya (Aji dan Mita,2010). Faktorfaktor yang diduga dapat mempengaruhi manajer untuk melakukan income smoothing yaitu profitabilitas, financial leverage dan dividen payout ratio. Praktik income smoothing membuat informasi yang terdapat pada laporan keuangan menjadi tidak relevan lagi. Sehingga pihak - pihak yang berkepentingan tidak bisa membuat keputusan yang tepat berdasarkan ketidak relevanan informasi pada laporan keuangan yang melatar belakangi penelitian ini.

Teori yang digunakan dalam penelitian ini adalah teori agensi, yaitu teori yang menjelaskan tentang hubungan kerja antara pemilik perusahaan (pemegang saham) dan manajemen. Teori keagenan mengasumsikan bahwa semua individu bertindak untuk kepentingan mereka sendiri. Teori agensi lahir dari pemikiran Berle and Means (1932) dalam skripsi Nur'aeni (2010) yang mengkaji penyerahan otoritas dari pemilik (owners) ke manajer (agent). Variabel yang digunakan dalam penelitian ini adalah earning manajemen, income smooting, profitabilitas, leverage dan deviden pay out rasio.

Earning management dapat didefinisikan sebagai intervensi manajemen dengan sengaja dalam proses penentuan laba, biasanya untuk memenuhinya tujuan pribadi Wild dkk (2005:120). Laporan keuangan disusun berdasarkan berbagai macam asaumsi yang diatur oleh standar yang ditetapkan oleh Dewan Standar Akuntansi Keuangan (DSAK). Subhekti (2008: 25) mendefinisikan income smoothing sebagai suatu alat yang digunakan manajemen untuk mengurangi fluktuasi laba yang dilaporkan agar sesuai dengan target yang diinginkan baik secara artifisial (melalui metode akuntansi) maupun secara riil (melalui transaksi). Profitabilitas merupakan kemampuan suatu perusahaan dalam menghasilkan laba pada periode tertentu.

Widyantari dkk, (2007) profitabilitas merupakan kemampuan suatu perusahaan untuk memperoleh laba dalam hubungannya dengan penjualan, total asset, maupun modal sendiri. Profitabilitas dapat diukur dengan menggunakan Return On Asset (ROA). 
Financial leverage merupakan tingkat sampai sejauh mana sekuritas laba tetap (hutang dan saham preferen) di gunakan dalam struktur modal perusahaan (Bringham dan Houston, 2006). Menurut Riyanto (1995) kebijakan dividen bersangkutan dengan penentuan pembagian pendapatan (earning) antara pengunaan pendapatan untuk dibayarkan kepada para pemegang saham sebagai dividen atau untuk digunakan didalam perusahaan, yang berarti laba tersebut harus ditahan didalam perusahaan.

\section{METODE}

Populasi dari penelitian ini adalah perusahaan manufaktur yang terdaftar di Bursa Efek Indonesia (BEI) selama periode 2014 - 2018. Peneliti menggunakan perusahaan manufaktur karena dianggap cukup mewakili karakter yang dibutuhkan dan data ini merupakan data yang tersedia selama penelitian dilakukan. Pengambilan sampel pada penelitian ini menggunakan purposive sampling method yaitu pengambilan sampel sesuai dengan kriteria tertentu.

\section{Jenis dan Sumber Data}

Seluruh data yang digunakan untuk mendukung penelitian ini menggunakan data sekunder, yaitu data yang telah ada dan tidak perlu dikumpulkan oleh peneliti serta diambil dari laporan keuangan tahunan perusahaan. Data sekunder tersebut berupa data untuk menghitung seluruh variabel yang digunakan yaitu income smoothing, profitabilitas, financial leverage, dividen payout ratio pada perusahaan Manufaktur yang terdaftar di Bursa Efek Indonesia periode tahun 2014-2018. Sumber data tersebut diperoleh dari situasi Bursa Efek Indonesia www.idx.co.id

\section{HASIL DAN PEMBAHASAN}

\section{Deskripsi Objek Penelitian}

Objek dalam penelitian ini adalah perusahaan manufaktur yang tercatat di Bursa Efek Indonesia (BEI). Berdasarkan data yang diperoleh dari BEI tercatat bahwa perusahaan manufaktur pada tahun 2014 hingga 2018 berjumlah 181 perusahaan. Jumlah perusahaan tersebut tidak seluruhnya diambil sebagai sampel karena tidak semua perusahaan memenuhi kriteria sebagai sampel penelitian. Metode pengambilan sampel dilakukan dengan cara purposive sampling.

\section{Uji Statistik Deskriptif}

Statistik deskriptif memberikan gambaran atau deskripsi mengenai suatu data yang dilihat dari nilai rata-rata (mean), standar deviasi, nilai terendah (minimum), dan nilai tertinggi (maksimum) (Ghozali, 2011). Statistik deskriptif variabel penelitian seperti pada tabel di bawah ini:

Tabel 1. Statistik Deskriptif

\begin{tabular}{crrrrr} 
& \multicolumn{1}{c}{ N } & \multicolumn{1}{l}{ Min } & \multicolumn{1}{c}{ Max } & \multicolumn{1}{c}{ Mean } & \multicolumn{1}{c}{ Std. Dev } \\
\hline PROF & 245 &, 08 & 52,67 & 9,38 & 8,709 \\
FIN & 245 & 9,15 & 634,06 & 98,58 & 103,479 \\
DEV & 245 &, 007 & 536,80 & 44,46 & 49,409 \\
IS & 245 & 0 & 1 &, 47 &, 500 \\
\hline
\end{tabular}

Sumber : Data Olahan 2020 


\section{Uji Asumsi Klasik \\ Uji Normalitas}

Uji normalitas bertujuan menguji apakah dalam model regresi variabel dependen dan variabel independen, keduanya memiliki distribusi normal atau tidak. Berdasarkan hasil output dari pengujian normalitas dengan grafik adalah sebagai berikut:

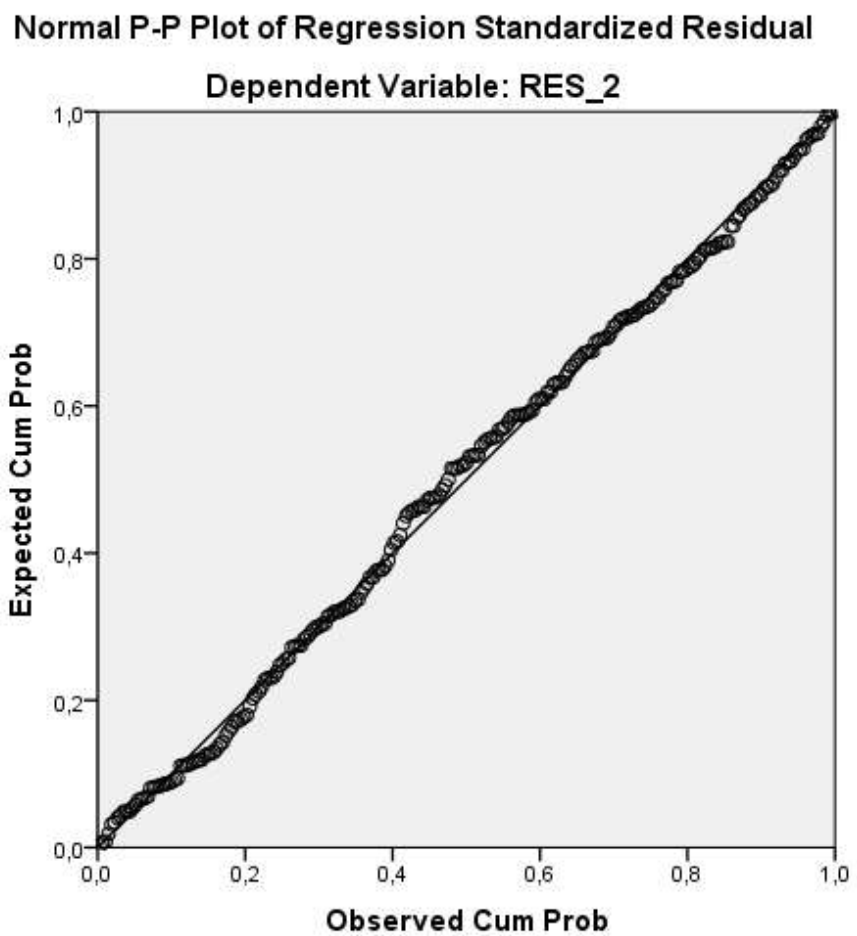

Gambar 1. Grafik P-plot

\section{Uji Heterokedastisitas}

Uji heterokedastisitas bertujuan menguji apakah model regresi terjadi ketidaksamaan variance dari residual satu pengamatan ke pengamatan yang lain (Ghozali, 2011).

Tabel 2. Hasil pengujian heteroskedastisitas

\begin{tabular}{|c|c|c|c|}
\hline Model & Beta & $t$ & Sig \\
\hline (Constant) & & 6,629 & ,000 \\
\hline PROF & ,074 & 1,083 & ,280 \\
\hline FIN & ,069 & 1,050 & 295 \\
\hline DIV &,- 028 &,- 421 & ,674 \\
\hline
\end{tabular}

Sumber : Data Olahan 2020

Berdasarkan hasil yang ditunjukkan dapat dilihat bahwa tidak ada satupun variabel independen yang signifikan secara statistik mempengaruhi variabel dependen yakni nilai Absolute Residual (ABS_RES). Hal ini terlihat dari nilai probabilitas signifikasinya yang di atas $5 \%$. sehingga dapat disimpulkan bahwa model regresi tidak mengandung adanya heterokedastisitas.

\section{Uji Autokorelasi}

Model regresi yang baik adalah tidak adanya autokorelasi. Untuk mengetahui ada tidaknya autokorelasi dengan melakukan uji Durbin Watson (DW test) (Priyatno, 2009: 61). Setelah nilai DW dibandingkan dengan nilai tabel yang menggunakan signifikansi 
$5 \%$, jumlah sampel (n) dan jumlah variabel independen (k). Jika dU < DW < 4-dU, maka dapat disimpulkan bahwa tidak ada autokorelasi dan sebaliknya (Priyatno, 2009).

Tabel 3. Hasil pengujian autokorelasi

\begin{tabular}{cccc} 
Model & R Square & Adjusted R Square & Durbin-Watson \\
\hline 1 &, 328 &, 320 & 1,985 \\
\hline
\end{tabular}

Sumber : Data Olahan 2020

Hasil uji autokorelasi dari variabel independen yaitu profitabilitas, financial leverage dan dividen payout ratio $(\mathrm{k}=3)$ menunjukkan nilai Durbin Watson sebesar 2,152 sedangkan nilai dL sebesar 1,7382 dan dU sebesar 1,7990 serta $4-\mathrm{dU}$ sebesar $4-1,7990=2,201$ yang diperoleh dari tabel Durbin Watson dengan tingkat signifikansi sebesar 0,05 dan sampel penelitian berjumlah 245. Berdasarkan kriteria uji autokorelasi dengan menggunakan Durbin Watson diperoleh hasil dU $<$ DW $<4-$ dU yaitu 1,7990 < 1,985 < 2,201 artinya di dalam model regresi tidak terjadi autokorelasi.

\section{Analisis Regresi Berganda}

Analisis regresi berganda digunakan untuk mengetahui besarnya pengaruh antara variabel bebas (independen) terhadap variabel terikat (dependen). Berdasarkan analisis dengan program SPSS diperoleh hasil regresi berganda seperti terangkum pada tabel berikut.

Tabel 4. Hasil pengujian regresi berganda

\begin{tabular}{|c|c|c|c|c|}
\hline & Model & Standardized Coefficients & $\mathbf{t}$ & Sig. \\
\hline & & Beta & & \\
\hline & (Constant) & & 3,780 & ,000 \\
\hline & PROF & ,340 & 5,325 & ,000 \\
\hline 1 & FIN & ,285 & 4,779 & ,000 \\
\hline & DIV &,- 061 &,- 959 & ,339 \\
\hline
\end{tabular}

Sumber : Data Olahan 2020

Berdasarkan tabel di atas diperoleh persamaan regresi berganda sebagai berikut:

$\mathbf{Y}=\mathbf{a}+\mathbf{b} 1 \mathbf{X} 1+\mathbf{b} 2 \mathbf{X} 2+\mathbf{b} 3 \mathbf{X} 3+\mathbf{e}$

$Y=219,832+0,020 X_{1}+0,001 X_{2}-0,070 X_{3}+e$

\section{Pengujian Hipotesis}

\section{Uji Koefisien Determinasi $\left(R^{2}\right)$}

Koefisien determinasi $\left(\mathrm{R}^{2}\right)$ mengukur seberapa jauh kemampuan model dalam menerangkan variasi variabel dependen (Ghozali, 2011). Hasil pengolahan SPSS didapatkan keofisien determinasi seperti di bawah ini.

Tabel 5. Hasil pengujian determinasi $\left(\mathrm{R}^{2}\right)$

\begin{tabular}{crr}
\hline Model & R Square & Adjusted R Square \\
\hline 1 &, 328 &, 320 \\
\hline Sumber: data diolah & &
\end{tabular}

Sumber: data diolah

Berdasarkan hasil uji koefisien determinasi $\left(\mathrm{R}^{2}\right)$ di atas menunjukkan bahwa $\mathrm{R}$ Square yang ditunjukkan sebesar 0,328 atau sebesar 32,8\%. Hal ini menunjukkan bahwa variabel dependen yakni Income Smoothing mampu dijelaskan oleh variabel independen, 
dalam penelitian ini profitabilitas, financial leverage dan dividen payout ratio sebesar $32,8 \%$. Sementara sisanya sebesar 67,2\% (100\%-32,8\%) dari variabel dependen Income Smoothing dipengaruhi oleh variabel independen lain yang tidak terdapat dalam penelitian ini.

\section{Uji Signifikansi Simultan (Uji F)}

Uji statistik F pada dasarnya menunjukkan apakah semua variabel independen atau bebas yang dimasukkan dalam model mempunyai pengaruh secara bersama-sama (simultan) terhadap variabel dependen atau terikat (Ghozali, 2011).

Tabel 6. Hasil pengujian simultan $\mathrm{F}$

\begin{tabular}{cccc}
\hline & Model & F & Sig. \\
\hline \multirow{3}{*}{1} & Regression & 15,372 &, $000^{\mathrm{b}}$ \\
& $\begin{array}{c}\text { Residual } \\
\text { Sumber : }\end{array}$ & & \\
\cline { 2 - 3 } & Data Olahan 2020 & &
\end{tabular}

Pada Tabel 4.14 menunjukkan besarnya nilai $F_{\text {hitung }}$ 15,372 $>F_{\text {tabel }}$ 2,642 (dan sig $0,000<0,05$ ). Hasil ini menunjukkan bahwa secara simultan (bersama-sama) variabel independen memiliki pengaruh signifikan positif terhadap variabel dependen artinya variabel independen yaitu profitabilitas, financial leverage dan dividen payout ratio mampu menjelaskan variabel dependen income smoothing.

\section{Uji Signifikansi Parsial (Uji t)}

Uji statistik t pada dasarnya menunjukkan seberapa jauh pengaruh satu variabel independen secara individual dalam menerangkan variasi variabel dependen.

\begin{tabular}{|c|c|c|c|c|}
\hline \multicolumn{2}{|c|}{ Model } & Standardized Coefficients & $\mathrm{t}$ & Sig. \\
\hline & \multicolumn{4}{|c|}{ Beta } \\
\hline \multirow{4}{*}{1} & (Constant) & & 3,780 &, 000 \\
\hline & PROF & ,340 & 5,325 &, 000 \\
\hline & FIN & ,285 & 4,779 & ,000 \\
\hline & DIV &,- 061 &,- 959 & ,339 \\
\hline
\end{tabular}

Sumber : Data Olahan 2020

\section{KESIMPULAN}

Penelitian ini dilakukan untuk menguji faktor-faktor yang berpengaruh terhadap incoming smooting pada perusahaan manufaktur yang terdaftar di Bursa Efek Indonesia tahun 2014-2018. Penelitian ini menggunakan sampel berjumlah 245 perusahaan dengan pemilihan sampel menggunakan purposive sampling. Berdasarkan hasil penelitian yang telah dilakukan, maka diperoleh kesimpulan sebagai berikut:

1. Profitabilitas secara parsial berpengaruh positif signifikan terhadap incoming smooting pada perusahaan manufaktur yang terdaftar di Bursa Efek Indonesia tahun 20142018.

2. Financial leverage secara parsial berpengaruh positif signifikan terhadap incoming smooting pada perusahaan manufaktur yang terdaftar di Bursa Efek Indonesia tahun 2014-2018. 
3. Dividen payout ratio secara parsial berpengaruh negatif tidak signifikan berpengaruh terhadap tindakan income smoothing pada perusahaan manufaktur yang terdaftar di Bursa Efek Indonesia tahun 2014-2018.

4. Profitabilitas, financial leverage dan dividen payout ratio secara simultan berpengaruh positif signifikan terhadap incoming smooting pada perusahaan manufaktur yang terdaftar di Bursa Efek Indonesia tahun 2014-2018.

\section{REFERENSI}

Abiprayu, Kris Brantas. (2011). Pengaruh Profitabilitas, Ukuran Perusahaan, Financial Leverage, Kualitas Audit, dan Dividend Payout Ratio Terhadap Income smoothing (Studi Kasus Pada Perusahaan Manufaktur Yang Terdaftar di Bursa Efek Indonesia Tahun 2006-2009).Skripsi. Semarang: Universitas Diponegoro.

Aji, Dhamar Yudo dan Aria Farah, Mita. (2010). Pengaruh Profitabilitas, Resiko Keuangan. Nilai Perusahaan, dan Struktur Kepemilikan Terhadap Praktek Income smoothing Studi Empiris pada Perusahaan Manufaktur Yang Terdaftar Di BEI. Skripsi. SNAXIII: Purwokerto.

Anthony, \& Govindarajan. (2005). Management Control System. Jakarta: Salemba Empat. Anthony, Robert N dan Govindarajan, Vijay. (2005). Sistem Pengendalian Manajemen. (Alih Bahasa: Kurniawan Tjakrawala dan Krista). Jakarta: Salemba Empat.

Berle, A dan G. Means, (1932). The Modern Corporation and Private Property, New York: Macmillan.

Brigham Eugene F and Joe F.Houston. (2006). Dasar-Dasar Manajemen Keuangan. Alih bahasa Ali Akbar Yulianto. Buku satu. Edisi sepuluh. Jakarta: Selemba Empat.

Brigham, E. F., \& Joel, F. H. (2011). Dasar-dasar Manajemen Keuangan. Jakarta: Salemba Empat.

Budiasih. (2009). Faktor-Faktor Yang Mempengaruhi Praktik Income smoothing :Jurnal Fakultas Ekonomi:Universitas Udayana.

Dwiatmini, Sesilia dan Nurkholis. (2001). Analisis Reaksi Pasar Terhadap Informasi Laba : Kasus Praktik Perataan Laba Pada Perusahaan yang Terdaftar di Bursa Efek Jakarta. Telaah Ekonomi, Manajemen, dan Akuntansi. Vol. III No I. Maret 2001. Hal 27-40.

Eckel, Norm. (1982). The Income Smoothing Hypothesis Revisited. Abacus, Vol 17, No. 1, June 1982, p.28-40.

Ghozali, \& Chariri. (2007). Teori Akuntansi. Semarang: Badan Penerbit Undip.

Ghozali, Imam. (2013). Aplikasi Analisis Multivariate dengan Program SPSS. Yogyakarta: Badan Penerbit BPFE.

Ghozali, Imam. (2016). Aplikasi Analisis Multivariete dengan Program IBM SPSS 23. Semarang: Badan Penerbit Universitas Diponegoro.

Jatinigrum. (2000). Analisis Faktor-Faktor yang Berpengaruh Terhadap Perataan Penghasilan Bersih atau Laba Pada Perusahaan yang Terdaftar di Bursa Efek Jakarta. Jurnal Bisnis dan Akuntansi. Vol.2. No.2, 145-155.

Jensen, M.C. dan Meckling, W.H. (1976). Theory of the Firm: Managerial Behavior, Agency Costs and Ownership Structure. Journal of Financial Economics, 3(4), pp. 305-360.

Komalasari, P.T. (1999). Model Perencanaan System Informasi: Suatu Perspektif Teori Agensi. JAAI, vol.3(2), hal.161-175.

Kosasih, Hebert. (2017). Analisis Pengaruh Kepemilikan Kas, Ukuran Perusahaan, Profitabilitas, Financial Leverage dan Kebijakan Dividen terhadap Praktik Perataan Laba pada Perusahaan Manufaktur yang terdaftar di Bursa Efek Indonesia (20122015). Skripsi. Universitas Sumatra Utara Medan.

Kumaladewi, Patricia Ratna. (2008). Pengaruh Perubahan Return on Assets, Perubahan Perating Profit Margin, dan Ukuran Perusahaan Terhadap Kemungkinan Praktek Income smoothing Pada Perusahaan Manufaktur Yang Terdaftar di Bursa Efek Indonesia. Skripsi. Yogyakarta : FE Universitas AtmaJaya Yogyakarta. 
Kustono, A. S., \& Sari, E. D. (2010). Pengaruh Profitabilitas dan Financial Leverage Terhadap Praktik Perataan Penghasilan Pada Bank-Bank di Indonesia. Media Riset Akuntansi, Vol. 7(2), 99-112.

Ma'ruf, Muhamad. (2006). Analisis Faktor-Faktor yang mempengaruhi Manajemen Laba Pada Perusahaan Go Public di Bursa Efek Jakarta. Skripsi.UII: Yogyakarta.

Nasir, A., \& Anna, S. (2002). Analisis Pengaruh Perataan Laba Terhadap Risiko Pasar Saham dan Return Saham Perusahaan-perusahaan Publik di Bursa Efek Jakarta. Kompak. Vol. 5: 139-15.

Nugroho, Saputro Adi. (2011). Pengaruh Book-Tax Differences terhadap Pertumbuhan Laba. Skripsi. Semarang : Fakultas Ekonomika dan Bisnis, UNDIP. Diunduh dari : Perpustakaan Elektronik UNDIP : http://www.eprint.undip.ac.id.

Nur'aeni, Dini. (2010). Pengaruh Struktur Kepemilikan Saham Terhadap Kinerja Perusahaan. Skripsi. Universitas Diponegoro Semarang

Rasinih, \& Musnandar, A. (2016). Pengaruh Financial Leverage dan Profitabilitas terhadap Income Smoothing dengan Kualitas Audit Sebagai Pemoderasi. Jurnal Ilmiah Akuntansi dan Bisnis. Vol.21 No.1, 41.

Riyanto, Bambang.(2010). Dasar-Dasar Pembelanjaan Perusahaan. Yogyakarta : BPFE.

Salno, H. M., dan Z. Baridwan. (2000). Analisa Perataan Penghasilan (Income Smoothing): Faktor-Faktor yang Mempengaruhi dan Kaitannya dengan Kinerja Saham Perusahaan Publik di Indonesia. Jurnal Riset Akuntansi Indonesia. Vol. 3. No. 1. Januari: 17-34.

Sartono. (2012). Manajemen Keuangan Teori dan Aplikasi Edisi 4. Yogyakarta : BPFE.

Subhekti, Yogi, (2008). Faktor-faktor yang Mempengaruhi Perataan Laba (income smoothing) dan Bukan Perataan Laba (non-income smoothing) (Studi pada Perusahaan yang Terdaftar di Bursa Efek Indonesia Tahun 2002-2006), Tesis, Program Studi Magister Manajemen, Universitas Sebelas Maret,Surakarta.

Sudjana. (1996). Teknik Analisis Regresi dan Korelasi. Bandung: Tarsito.

Sularto, Lana. (2007). Pengaruh Ukuran Perusahaan, Profitabilita, Leverage dan Tipe Kepemilikan Perusahaan Terhadap Luas Voluntary Disclousure Laporan Keuangan. Vol2. Auditorium Kampus Ghunadarma. ISSN: 1858-2559.

Syahriana, N. (2006). Analisis Perataan Laba Dan Faktor-Faktor Yang Mempengaruhi Pada Perusahaan Manufaktur Di Bursa Efek Jakarta (2000 - 2004). Skripsi, Universitas Islam Indonesia.

Syamsudin, Lukman. (2004). Manajemen Keuangan Perusahaan Jakarta : PT. Raja Grafindo Persada.

Tandelilin, Eduardus. (2001). Analisis Investasi dan Manajemen Portofolio. Yogyakarta : PT. BPFE.

Tandelilin, Eduardus. (2010). Portofolio dan Investasi teori dan aplikasi, Edisi Pertama. Yogyakarta : KANISIUS.

Trisnawati, Mufarrokhah., Mohamad R. Nazar, Siska P. Yudowati. (2017) Pengaruh Profitabilitas, Dividen Payout Ratio dan Financial Leverage terhadap Praktik Perataan Laba (2011-2016). E-proceeding of Management, Vol. 4 No.3, hal 26542660.

Warsono. (2003). Manajemen Keuangan Perusahaan. Jilid 1. Bayu Media Publishing. Malang.

Wild, John J., K. R. Subramanyam, dan Robert F. Halsey, (2005). Analisis Laporan Keuangan, Buku 1, Edisi 8, Alih Bahasa Yanivi S. Bachtiar dan S. Nurwahyu Harahap, Salemba Empat, Jakarta.

Wulandari, S., \& Purwaningsih, A. (2007). Pengaruh Ukuran Perusahaan, Profitabilitas, dan Leverage Operasi Terhadap Praktik Perataan. Jurnal Ekonomi dan Bisnis, Vol. 19 No.1, 49-61 